\title{
Effects of Antioxidants in Controlling Phenolic Exudates in in vitro Culture of Gliricidia [Gliricidia sepium (Jacq.) Steud.]
}

\author{
Aparna $^{1^{*}}$, M.L. Jakhar ${ }^{1}$, Rahul Kumar Tiwari ${ }^{3}$ and Leela Bhatt ${ }^{2}$ \\ ${ }^{1}$ Department of Plant Breeding and Genetics, ${ }^{2}$ Department of Horticulture, SKNAU Jobner, India \\ ${ }^{3}$ Division of Plant Pathology, IARI, New Delhi, India \\ *Corresponding author
}

\section{A B S T R A C T}

\begin{tabular}{|l|}
\hline Key y or d s \\
Cytokinins, \\
Antioxidant, Micro \\
propagation and \\
Gliricidia.
\end{tabular}

The present investigation was carried out to study the influence of antioxidants on in vitro culture of Gliricidia sepium. Soft nodal stem segments were inoculated on MS medium supplemented with desired concentrations plant growth regulator such as cytokinins (BAP/Kinetin) and different antioxidants. Antioxidants viz., activated charcoal, ascorbic acid, citric acid and polyvinylpyrollidone were used to control the accumulation of phenolic compounds in the culture medium and enhance the rate of micropropagation. All cultures were incubated at $25+2{ }^{0} \mathrm{C}$ under fluorescent light in a 14: 10 hour's photoperiod. Maximum number of shoot bud induction was obtained when MS medium is supplemented with 0.5 $\mathrm{mg} / \mathrm{l}$ and $250 \mathrm{mg} / \mathrm{l}$ ascorbic acid.

\section{Introduction}

Gliricidia sepium is a medium-sized leguminous tree.It belongs to family Fabaceae. It has diploid number chromosomes $2 \mathrm{n}=22$. Central America and possibly South America are believed to be native place of this forage tree (Hughes, 1987 and Lavin and Sousa, 1995). It is distributed over Tropical America, Africa and Fiji. It is an introduced forage tree in India. In India, it is mainly cultivated in Tamil Nadu, Andhra Pradesh, Maharashtra and Karnataka.

Gliricidia sepium can perform well on marginally saline vertisols. There is a hermaphrodite flowering system coupled with obligate outcrossing and a strong selfincompatibility mechanism (WAC, 2005). $G$. sepium is an extremely versatile nitrogenfixing agroforestry tree that can be incorporated in diverse ways into many different smallholder farming systems and provide a range of wood and leaf products including fuelwood, construction poles, crop supports, green manure, fodder and bee forage (Simons and Stewart, 1994; Stewart, 1996). In many areas seed setting is extremely low and natural regeneration is poor. Seed setting is a major problem in the arid condition along with germination of seed. It hinders its propagation at a large scale. 
Considering these problems and limitations, present study has been undertaken to explore potential of in vitro multiplication for large scale propagation. Micropropagation technology offers many advantages when compared with other more conventional propagation methods. It was noticed that plant phenolic increased the rigidity of plant cell wall and acted as a molecular bridges between cell wall components (Ozyigit, 2008). During micropropagation, the exudation is very common and it often influences the results. Phenolic secretions and other exudates in plant tissue culture systems lessen explant initiation, growth, and development (Kerns et al., 1986). The antioxidant has been successfully used in past to inhibit the exudation of phenols and reduced oxidative browning in various plant species (Abdelwahd et al., 2008)

\section{Materials and Methods}

In order to observe the effect of different antioxidant, present research was conducted. Soft nodal stem segments of Gliricidia sepium were used as explant. Explants were washed with detergent and rinsed with running tap water to remove dirt. Soft stem nodal segments were cut into $1.5 \mathrm{~cm}$ to $2.0 \mathrm{~cm}$ length with single node. In laminar airflow chamber, explants were sterilized with 0.1 percent mercuric chloride and finally used for raising in vitro cultures.

Murashige and Skoog (1962) medium was used throughout the course of investigation. MS medium were supplemented with desired concentration plant growth regulator such as cytokinins (BAP/Kinetin) and different antioxidants. Antioxidants viz: activated charcoal, ascorbic acid, citric acid and polyvinylpyrollidone were used to control the accumulation of phenolic compounds in the culture medium and enhance the rate of micropropagation. Different concentrations of various antioxidant were tested at most responsive level of plant growth regulators where maximum shoot development was observed. Following levels of antioxidants were used:

Activated charcoal $(0.5,1.0,1.5,2.0,2.5$ and $3.0 \mathrm{~g} / \mathrm{l})$.

Ascorbic acid (50,100,150, 200, 250 and 300 $\mathrm{mg} / \mathrm{l})$.

Citric acid (10, 20, 30, 40, 50 and $60 \mathrm{mg} / \mathrm{l})$.

Polyvinylpyrrolidone $(0.5,1.0,1.5,2.0,2.5$ and $3.0 \mathrm{mg} / \mathrm{l})$.

The $\mathrm{pH}$ of the culture medium was adjusted at 5.84 using $1 \mathrm{~N} \mathrm{NaOH}$ or $1 \mathrm{~N} \mathrm{HCl}$ solution before autoclaving. The culture media were autoclaved at $15 \mathrm{psi}$ and $121{ }^{\circ} \mathrm{C}$ for $15-40$ minutes. After sterilization the explants were inoculated on culture media aseptically. For inoculation, explants were transferred to large sterile glass petriplates with the help of sterile forceps under strict aseptic conditions. Explants of suitable size were transferred to culture test tubes, phyta jars and borosil flasks containing MS medium supplemented with different plant growth regulator and antioxidants. All cultures were incubated at $25+2^{0} \mathrm{C}$ under fluorescent light in a 14: 10 hour's photoperiod.

Each treatment combination was replicated 10 times and whole experiment was repeated twice to obtain unbiased results. Cultures were observed periodically and following observations were recorded: Percentage of explants producing shoot, Number of shoots/explant, Percentage of explants producing root, Number of roots/explant and Number of days taken to for development of shoots and roots. The experiment was conducted in completely randomized design and data were analyzed for mean and standard error. 


\section{Results and Discussion}

The most striking effect of bud break and shoot multiplication have been found with many antioxidant (Wang et al., 2002 and Ujjwala, 2006). Activated charcoal, ascorbic acid, citric acid and polyvinylpyrollidone are most commonly used antioxidants for micropropagation.

In present study, when different antioxidants incorporated singly in MS medium supplemented with responsive level $(0.5 \mathrm{mg} / \mathrm{l}$ BAP) of plant growth regulator for shoot multiplication elicited different response for shoot bud induction because it controls the accumulation of inhibitory substance (phenolic compounds) in the growth medium.

\section{Effect of activated charcoal}

When activated charcoal is added in the basal MS medium with micropropagation protocol $(0.5 \mathrm{mg} / \mathrm{l} \mathrm{BAP})$, it induced shoots at all the levels $(0.5-3.0 \mathrm{~g} / \mathrm{l})$. Maximum number of shoot bud (5.0) was observed at $2.0 \mathrm{~g} / \mathrm{l}$ with 100 per cent frequency (Table 1). The result found in case of activated charcoal was in close agreement with effect of antioxidant on micropropagation in other crops $(\mathrm{Wu}$ and $\mathrm{Xi}$, 2002) where activated charcoal was prime antioxidant used for successful shoot multiplication. In other studies, North et al., (2012) recorded 53\% reduction of phenols in media supplemented with activated charcoal in Strelitziareginae.

Fig.1 Shoot induction in Gliricidia sepium on MS medium supplemented with $0.5 \mathrm{mg} / 1 \mathrm{BAP}$ and $250 \mathrm{mg} / \mathrm{l}$ ascorbic acid

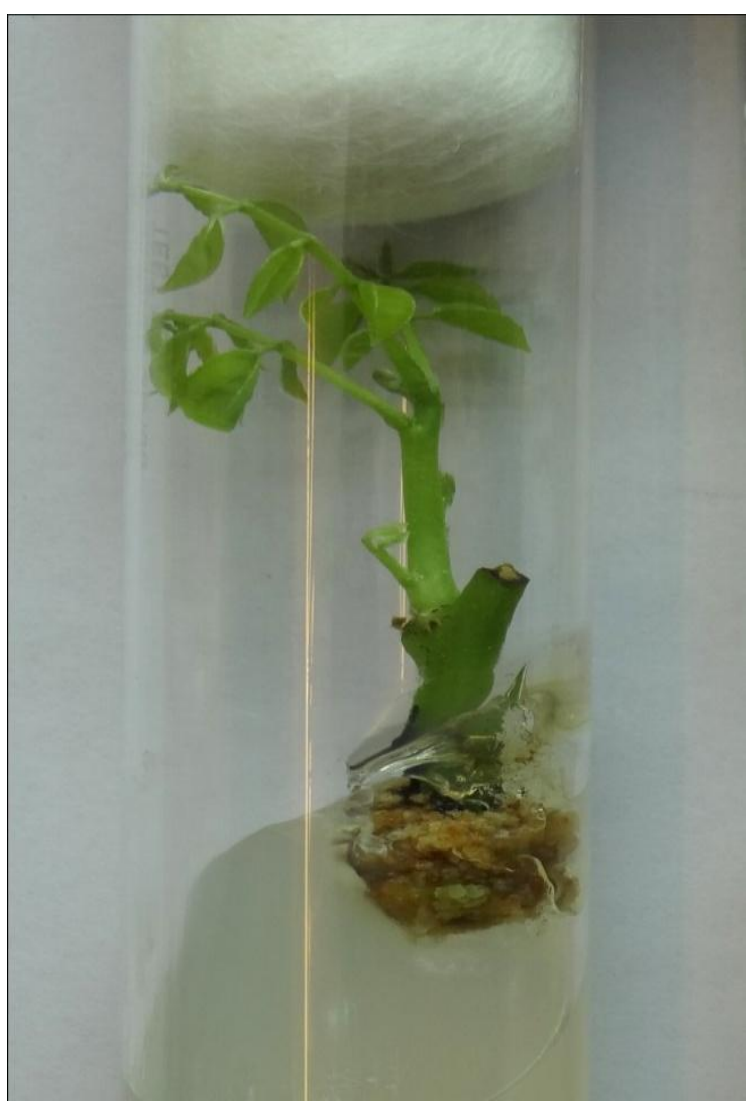


Table.1 Effect of different antioxidants supplemented in the MS medium along with $0.5 \mathrm{mg} / \mathrm{l}$ BAP on shoot bud induction in Gliricidia sepium

\begin{tabular}{|c|c|c|c|c|c|c|c|c|c|c|c|}
\hline \multicolumn{12}{|c|}{ Morphogenetic response of soft nodal stem segment on different antioxidants } \\
\hline \multicolumn{3}{|c|}{ Activated charcoal } & \multicolumn{3}{|c|}{ Ascorbic acid } & \multicolumn{3}{|c|}{ Citric acid } & \multicolumn{3}{|c|}{ Polyvinylpyrollidone } \\
\hline $\begin{array}{l}\text { Concen- } \\
\text { tration } \\
\text { (g/l) }\end{array}$ & $\begin{array}{c}\text { No of } \\
\text { shoot } \\
\text { buds } \\
\text { /explant } \\
\text { Mean } \pm \\
\text { SE } \\
\text { n =10 }\end{array}$ & $\begin{array}{c}\text { Frequency } \\
(\%)\end{array}$ & $\begin{array}{l}\text { Concentr } \\
\text { ation } \\
\text { (mg/l) }\end{array}$ & $\begin{array}{c}\text { No of } \\
\text { shoot bud } \\
\text { /explant } \\
\text { Mean } \pm \\
\text { SE } \\
\text { n }=10\end{array}$ & $\begin{array}{c}\text { Frequency } \\
(\%)\end{array}$ & $\begin{array}{l}\text { Concentr } \\
\text { ation } \\
\text { (mg/l) }\end{array}$ & $\begin{array}{c}\text { No of } \\
\text { shoot } \\
\text { buds } \\
\text { /explant } \\
\text { Mean } \pm \\
\text { SE } \\
\text { n =10 }\end{array}$ & $\begin{array}{c}\text { Frequency } \\
(\%)\end{array}$ & $\begin{array}{l}\text { Concentr } \\
\text { ation } \\
\text { (mg/l) }\end{array}$ & $\begin{array}{c}\text { No of } \\
\text { shoot } \\
\text { buds } \\
\text { /explant } \\
\text { Mean } \pm \\
\text { SE } \\
\text { n =10 }\end{array}$ & $\begin{array}{c}\text { Frequency } \\
(\%)\end{array}$ \\
\hline 0.5 & $3.1 \pm 0.21$ & 80 & 50 & $3.2 \pm 0.24$ & 60 & 10 & $3.8 \pm 0.13$ & 80 & 0.5 & $2.4 \pm 0.16$ & 60 \\
\hline 1.0 & $3.2 \pm 0.24$ & 80 & 100 & $3.6 \pm 0.16$ & 60 & 20 & $3.2 \pm 0.20$ & 80 & 1.0 & $2.6 \pm 0.26$ & 60 \\
\hline 1.5 & $4.1 \pm 0.17$ & 80 & 150 & $3.8 \pm 0.13$ & 60 & 30 & $3.0 \pm 0.21$ & 60 & 1.5 & $3.1 \pm 0.10$ & 60 \\
\hline 2.0 & $5.0 \pm 0.34$ & 100 & 200 & $4.0 \pm 0.21$ & 80 & 40 & $2.4 \pm 0.22$ & 60 & 2.0 & $3.5 \pm 0.16$ & 80 \\
\hline 2.5 & $3.3 \pm 0.21$ & 80 & 250 & $5.1 \pm 0.17$ & 100 & 50 & $2.2 \pm 0.13$ & 60 & 2.5 & $3.4 \pm 0.22$ & 60 \\
\hline 3.0 & $4.2 \pm 0.2$ & 80 & 300 & $4.6 \pm 0.22$ & 80 & 60 & $2.3 \pm 0.15$ & 40 & 3.0 & $2.8 \pm 0.13$ & 60 \\
\hline
\end{tabular}




\section{Effect of ascorbic acid}

When ascorbic acid is added in the MS medium with micropropagation protocol $(0.5$ $\mathrm{mg} / \mathrm{l} \mathrm{BAP}$ ), it induced shoot buds at all the levels $(50-300 \mathrm{mg} / \mathrm{l})$. Maximum number of shoot bud induction (5.1) was observed at 250 $\mathrm{mg} / \mathrm{l}$ ascorbic acid level with 100per cent frequency (Fig. 1). Minimum number of shoot bud (3.2) was obtained $50 \mathrm{mg} / \mathrm{l}$ with 60 per cent shoot bud induction frequency (Table 1). Ndakidemi et al., (2014) established that the best result for controlling lethal browning was obtained when $B$. huillensis nodal segments were cultured on medium supplemented with $5 \mu \mathrm{M}$ BAP and incorporated with $200-250$ $\mathrm{mg} / \mathrm{litre}$ of ascorbic acid which is in close agreement with the present investigation.

\section{Effect of citric acid}

Supplementation of citric acid in the basal MS medium containing $0.5 \mathrm{mg} / \mathrm{l} \mathrm{BAP}$ induced shoots at all the levels $(0.5-3.0 \mathrm{mg} / \mathrm{l})$. Maximum shoot bud (3.8) was observed at 10 $\mathrm{mg} / \mathrm{l}$ citric acid with 80 per cent shoot bud induction frequency. Increasing level of citric acid in medium showed decrease in number of shoot multiplication. The frequency of shoot multiplication ranged from $40-80$ per cent (Table 1).

\section{Effect of polyvinylpyrrolidone}

Addition of polyvinylpyrrolidone in culture vessels with responsive level of plant growth regulator $(0.5 \mathrm{mg} / \mathrm{l} \mathrm{BAP})$ did not show very good results on shoot multiplication in explants. It induced shoots at all the levels (0.5- $3.0 \mathrm{mg} / \mathrm{l})$. Maximum shoot bud (3.0) was observed at $3.0 \mathrm{mg} / \mathrm{l}$ with 80 per cent shoot bud induction frequency (Table 1).

In conclusion, it was found that addition of ascorbic acid $(250 \mathrm{mg} / \mathrm{l})$ in the MS medium with $0.5 \mathrm{mg} / \mathrm{l} \mathrm{BAP}$ appeared most optimum level of antioxidant for maximum shootbud proliferation and in controlling harmful effect of phenolic compounds in culture medium with 100 per cent frequency followed by 2.0 $\mathrm{g} / \mathrm{l}$ level of activated charcoal. Polyvinylpyrrolidone was found to be least effective in controlling harmful effect of phenolic compounds.

\section{References}

Abdelwahd, R.N., Hakam, M., Labhilili, S.M., and Udupa., 2008.Use of an absorbant and antioxidant to reduce the effects of leached phenolics in in vitro plantlet regeneration of Faba Bean. African Journal of Biotechnology, 7(8), 997-1002.

Hughes, C. E., 1987. Biological considerations in designing a seed collection strategy for Gliricidia sepium (Jacquin) Steudel (Leguminosae). Commonwealth Forestry Review. 66, 31.

Kerns, H. R., and Meyer Jr, M. M. 1986.Tissue Culture Propagation of Acer Freemanii using thidiazuron to stimulate shoot tip proliferation. Hort Science. 21, 1209-1210.

Lavin, M., and Sousa, M. 1995.Phylogenetic systematics and biogeography of the tribe Robinieae (Leguminosae). Systematic Botany Monographs.45, 1160.

Murashige, T., and Skoog, F. 1962.A revised medium for rapid growth for a bioassay with tobacco tissue cultures. Plant Physiology. 115, 493 - 497.

Ndakidemi1, C.F., Mneney, E. and Ndakidemi1, P.A.2014. Effects of ascorbic acid in controlling lethal browning in in vitro culture of Brahylaena huillensis using nodal segments. American Journal of Plant Sciences.5:187-191.

North, J. J., Ndakidemi, P. A., and. 
Laubscher, C. P. 2012. Effects of antioxidants, plant growth regulators and wounding on phenolic compound excretion during micropropagation of Strelitziareginae. International Journal of the Physical Sciences. 7 (4), 638-646.

Ozyigit, I. I. 2008.Phenolic Changes during in Vitro Organogenesis of Cotton (Gossypium hirsutum L) Shoot Tips. African Journal of Biotechnology.7: 1145- 1150.

Simons, A.J., and Stewart, J.L. 1994.Gliricidia sepium- a multipurpose forage tree legume. Forage tree legume in tropical agriculture. 5, 30-48

Stewart, J.L., 1996. Utilization. In: Stewart JL, Allison GE, Simons AJ, eds. Gliricidia sepium. Genetic Resources for Farmers. Tropical Forestry Paper 33. Oxford, UK: Oxford Forestry Institute. 33-48.

Ujjwala, S. J., 2006. Plant tissue culture laboratory. St. Thomas College, Bhilai (CG) 490006.

WAC, 2005.Agroforestree database. World Agroforestry Centre: Nairobi, Kenya.

Wang, L., Zheng, S. X., and Gu, Z. J. 2002. In vitro culture of tetraploids of Aloe vera (L.).Acta-Horticulturae Sinicaa. 29 (2), 176-178.

Wu, Y. X, and Xie, Q. H. 2002. Some influencial factors for shoot organogenesis and plant regeneration in Aloe vera. South West China Journal of Agricultural Sciences.15, 190 -192.

\section{How to cite this article:}

Aparna, M.L. Jakhar, Rahul Kumar Tiwari and Leela Bhatt. 2017. Effects of Antioxidants in Controlling Phenolic Exudates in in vitro Culture of Gliricidia [Gliricidia sepium (Jacq.) Steud.]. Int.J.Curr.Microbiol.App.Sci. 6(12): 4291-4296. doi: https://doi.org/10.20546/ijcmas.2017.611.504 